\title{
DIRECTIONS OF PERFECTION PHYSICAL EDUCATION CHILDREN OF PRESCHOOL AGE USING THE GAMING FUNDS
}

\author{
Bakhtiyor Choriyevich Berdiyev
}

Teacher, Department of “Sports Management”, Termez State University Uzbekistan

\section{ABSTRACT}

The paper deals with the optimization of the process of physical training of children of preschool age. Based on a holistic analysis presented in the special scientific and methodical literature data we studied a number of modern ways to improve the content and organization of the process of physical education of preschool children through the use of gaming funds. It is shown that the widespread use of gaming technology in the practice of physical education of preschool education contributes to the accumulation of the motor experiences of children; improve emotional potential, physical, moral and intellectual development.

KEYWORDS:- Game technologies, preschool institutions, preschool age, improvement, optimization, physical education, game tools.

\section{INTRODUCTION}

At the present stage, the problem of human health appears as one of the most acute and requires a serious attitude to its solution with the involvement of various organizational structures. This situation is of particular importance in the system of upbringing of preschool children, since recently in Uzbekistan, as in other countries, a tendency has been revealed for the deterioration of their health.

The solution to these problems is largely associated with physical education, which is an important means of shaping the health of a person. According to leading scientists, it is physical education that is a type of activity that contributes to the education of the best physical, moral, intellectual, mental qualities and is associated with the formation of a harmonious personality and his health. An important direction of physical education of preschool children is the use of various forms and means of physical improvement, among which an important place is given to play activity $[1, \mathrm{p}$. 262].

\section{THE MAIN FINDINGS AND RESULTS}

As you know, preschool age is the most crucial stage in the development of an organism and the most important in the formation of a personality. During this period, the foundations of health, full-fledged physical development, and physical fitness are laid; the biological prerequisites for 
CURRENT RESEARCH JOURNAL OF PEDAGOGICS 2(10): 07-11, October

2021 DOI: https://doi.org/10.37547/pedagogics-crjp-02-10-02

ISSN 2767-3278

(C)2021 Master Journals

\section{Crossref do) 8 Google}

Accepted 08 ${ }^{\text {th }}$ October, 2021 \& Published $13^{\text {th }}$ October, 2021

personal development, the formation of mental processes are stabilized. The importance and uniqueness of preschool childhood is emphasized by the fact that this age stage is specific, the features of which are determined by its leading activity - play [2, pp. 405-413].

\section{Methods}

In this context, the introduction of new progressive pedagogical technologies, namely play technologies, into the process of physical education of preschool children is of particular interest. The aim of the study was to study modern approaches to the implementation of play tools in the practice of physical education of preschool children. Analysis and generalization of scientific and methodological literature, system analysis and comparison were chosen as the research methods.

In the fundamental works of many famous scientists and researchers it is noted that one of the priority means of harmonious development, the formation of the child's motor, volitional, intellectual and moral qualities is organized play activity.

Let us dwell on such an innovation developed and tested by Zh.L. Kozina [3, p. 78]. This is a special game gymnastics "Little Wizards", where poems and fairy tales are used in story games. The purpose of the methodology is a harmonious combination of intellectual, speech, social, emotional, artistic, physical, moral, aesthetic and spiritual education of children in a single compact set of game exercises and poems about nature. The methodological features of special gymnastics are the presence of a sufficiently large number of exercises, the construction of exercises according to the principle of alternating heavy with light, purely imitative, which makes it possible to alternate loads and rest.

In the context of our research, the implementation of gaming technologies with the use of special equipment, fixtures and fittings is of particular interest. One of such innovations is the system of game technologies with elements of sports by D. Turdimurodov [4, pp. 47-51]. The proposed technologies functionally, holistically and integrally combine various elements of teaching and upbringing of a child aged 2-4 years. The game technology of integrating the development of fine motor skills and the development of skills for systematization, classification, imagination, creativity and communication skills consists in the application of the development of outdoor games.

Another modern approach is the developed project of a children's playground that meets the requirements of a comprehensive systemic upbringing of a child, combining mental, volitional and physical development. The site has "stations" where you need to do math tasks, exercise, and the like. "Stations" have dimensions corresponding to the child's height, and therefore, in order to complete the task, the child must perform certain movements, move from station to station in any prescribed motor way [5].

The main objective of the program is to develop the physical and cognitive abilities of preschool children. The relationship between physical and mental education is reflected in the implementation of inter-subject connections, when motor actions in game exercises, outdoor games and relay races are performed accompanied by questions, poems, counting rhymes, riddles and chess games.

For the mental development of preschool children in the process of games in physical education classes, it is especially important to form a steady interest in the process of movements and motor actions, to evoke a feeling of joyful expectation, to teach the child to be attentive. In this case, it is not the entertainment 
CURRENT RESEARCH JOURNAL OF PEDAGOGICS 2(10): 07-11, October

2021 DOI: https://doi.org/10.37547/pedagogics-crjp-02-10-02

ISSN 2767-3278

(C)2021 Master Journals

\section{Crossref do) 8 Google}

Accepted 08 ${ }^{\text {th }}$ October, 2021 \& Published $13^{\text {th }}$ October, 2021

interest that is important, which has a short-term effect, but the interest of searching, thinking. N.N. Norboev proved the effectiveness of using the motivational-need component associated with the development of physical qualities and mental processes in the process of playing chess in physical education classes for children [6, pp. 4347].

An important role in the development of the motor and cognitive component in children is played by the functional use of play activity through the selection of games that combine the performance of physical and mental tasks. In the study, the author proved the effectiveness of using role-playing games, which are based on the system of role-playing gymnastics. The content of this system is the synthesis of physical culture means, various types of art (choreography, dance, music, theater) [7].

The effectiveness of the program for the integrated development of physical abilities and thinking by means of game activity in the process of physical education was substantiated by Kh.A. Menglikulov. The pedagogical conditions for the implementation of the program are the complex use of mobile, plot-role-playing games and game exercises, differentiated on the basis of the predominant development of physical abilities and thinking, which are due to the time of their implementation in the daily routine. In the process of implementing the program, preschoolers consistently performed mobile and role-playing games specially selected for this purpose, as well as game exercises for the development of thinking, in which the predominant development of one of the five physical qualities was combined with one or several types of thinking [8].

The research of D.Y. Turdimurodov consists in the development and substantiation of an innovative methodology of the directed impact of outdoor games on the development of communication skills and volitional qualities of preschool children. The experimental program consists of three groups of outdoor games (outdoor games with the advantage of the individual character of the participants' actions, pair outdoor games, where along with individual actions there are joint actions of a small group of participants, team games of a competitive nature), which are implemented using game and competitive methods in certain forms of work, physical culture and recreational activities during the day and active rest [9, pp. 13481354].

To activate the cognitive activity of preschoolers by means of physical education, play material is offered, aimed at the development of cognitive activity and motor qualities in preschoolers, in particular, at the establishment of elementary knowledge in physical education. In this regard, the first group included games aimed at cognition. The second group includes games aimed at learning the basic types of movements. The third group is made up of games that require knowledge of the basic terms of developmental exercises. The fourth group - games for learning the methods of ball control [10, pp. 1348 - 1354].

The formation of physical culture of the personality of preschoolers in the motor mode of the day can be effective with an increase in the total volume of games in all forms of physical education, through varying outdoor games and game tasks, different in intensity, with the predominant use of games of medium intensity. This contributes to the greater physical and intellectual development of children in comparison with the traditional planning of the motor regime of a children's educational institution [11, pp. 381-383].

\section{Results}

In modern theory and practice of preschool physical education, considerable attention is paid 
CURRENT RESEARCH JOURNAL OF PEDAGOGICS 2(10): 07-11, October

2021 DOI: https://doi.org/10.37547/pedagogics-crjp-02-10-02

ISSN 2767-3278

(C)2021 Master Journals

\section{Crossref dof 81 Google}

Accepted 08th October, 2021 \& Published $13^{\text {th }}$ October, 2021

to the optimal combination of various forms, methods and means of teaching and upbringing, allow you to effectively solve the problems of existing programs. And in this vein, one of the important means of physical education of preschool children is folk outdoor games, in which the physical and emotional-volitional qualities of preschoolers are comprehensively brought up, as well as motor skills and abilities are formed. The author focuses on the use of elementary verbal-motor games, finger games, games-amusements for various parts of the body, which are performed accompanied by songs and poems. The widespread use of these games contributes to the accelerated development of fine motor skills and the strengthening of the muscles of the legs and trunk.

D.Y. Turdimurodov believes that outdoor folk games are an integral part of the physical and moral-volitional education of preschoolers. The researcher proposes the technology of upbringing volitional and moral qualities in the process of physical exercises. The means of physical education are precisely the environment (natural and social), role-playing games, active game exercises, games and relay races, which are subordinated to sports topics. The joy of movement is combined with the spiritual enrichment of children. They form a steady interest in physical education, respect for the culture of their native country; create an emotionally positive basis for the development of patriotic feelings, education of mind, character, will, moral feelings [12, pp. 64-74].

\section{Discussion}

Studying various game innovations for improving the system of physical education of preschool children, one should focus on introducing not only mental and outdoor games into the educational process, but also information technology games. One of these vectors of modernization is the principles of differentiation of outdoor games in the physical education of preschoolers, which determine the system of criteria for the classification of outdoor games. The main form of differentiated learning will be motor tasks created for each subgroup of children, distributed according to physical fitness into low, medium and high.

\section{Conclusions}

Analysis of scientific and methodological literature has shown that play occupies the leading place at the stage of preschool ontogenesis. A number of studies indicate the deep interest of scientists in solving the problem of developing and introducing gaming technologies into the practice of physical education of preschool children. As you can see, gaming technologies have great opportunities for the development of physical capabilities, cognitive processes, moral-volitional, social, communication skills and character of the child. Thus, a systematic approach to the use of gaming technologies will allow optimizing the process of physical education of preschool children.

\section{REFERENCES}

1. Glazyrina L.D. (1999) Physical culture for preschoolers: older age. - Moscow: VLADOS. - p. 262. (Глазырина Л. Д. Физическая культура дошкольникам: старший возраст. - Москва : ВЛАДОС, 1999. - 262 c.)

2. Turdimurodov, D. Y. (2021). Testing volitional qualities for students of high schools of secondary school. The American Journal of Social Science and Education Innovations, 3(03). - pp. 405-413.

3. Kozina J.L. (2009) Little Magicians. Cheerful children's gymnastics in verse: Textbook. Allowance / Zh.L. Kozina, V. Yu. Kozin. - 3rd 
CURRENT RESEARCH JOURNAL OF PEDAGOGICS 2(10): 07-11, October

2021 DOI: https://doi.org/10.37547/pedagogics-crjp-02-10-02

ISSN 2767-3278

(C)2021 Master Journals

Crossref dof 81 Google

Accepted 08 ${ }^{\text {th }}$ October, 2021 \& Published $13^{\text {th }}$ October, 2021

ed., Add. - Kharkov. - p. 78. (Козина Ж. Л. Маленькие волшебники. Веселая детская гимнастика в стихах : учеб. пособие / Ж. Л. Козина, В. Ю. Козин. - 3-е изд., доп. Харьков, 2009. - 78 с.)

4. Turdimurodov, D. Y. (2021). Preschool period: pedagogical aspect of education of will in a child. Current Research Journal of Pedagogics (2767-3278), 2(09), 47-51.

5. Alikulovich, M. K., \& Yuldashevich, T. D. (2020). Development of physical training skills and formation of willpower qualities in extracurricular activities. European Journal of Research and Reflection in Educational Sciences Vol, 8(3).

6. Norboyev, N. N. (2020). The most ancient chess in the world detected in Uzbekistan. Theoretical \& Applied Science, (10), 43-47.

7. Abdullaev, Ya.M., \& Yuldashevich, T. D. (2020). Creation of pedagogical conditions in the formation of volitional grades in primary school students. In Colloquiumjournal (No. 24 (76)). Holoprystan City and District Employment Center. (Абдуллаев, Я. М., \& Юлдашевич, Т. Д. (2020). Создание педагогических условий в формировании волевых качеств у учеников начальных классов. In Colloquium-journal (No. 24 (76)). Голопристанський міськрайонний центр зайнятості.)

8. Menglikulov, Kh.A. (2020). Features of physical training of physical culture specialists in a higher educational institution. Innovations in pedagogy and psychology, 11 (3). (Менгликулов, Х. А. (2020). Особенности физической подготовки специалистов физической культуры в высшем учебном заведении. Педагогика ва психологияда инновациялар, 11(3).)

9. Turdimurodov, D. Yu. (2021). Features of the manifestation of volitional efforts in the process of external stimulation in schoolchildren of 10-12 years old. Academic research in educational sciences, 2 (4). - pp. 1348-1354. (Турдимуродов, Д. Ю. (2021). Особенности проявления волевых усилий в процессе внешней стимуляции у школьников 10-12 лет. Academic research in educational sciences, 2(4), 1348-1354.)

10. Turdimurodov D. Yu. (2021) Features of manifestation of volitional efforts in the process of external stimulation in schoolchildren of 10-12 years old. D. Yu. Turdimurodov. Academic research in educational sciences. Volume 2. issue 4. - pp. 1348 - 1354. (Турдимуродов Д. Ю. Особенности проявления волевых усилий в процессе внешней стимуляции у школьников 10-12 лет / Д. Ю. Турдимуродов // Academic research in educational sciences. - 2021. volume 2. issue 4. - C. 1348 - 1354.)

11. Abdullaev, Ya.M. (2012). Development of physical education of the younger generation in lifelong education. Young Scientist, (11). -pp. 381-383. (Абдуллаев, Я. М. (2012). Развитие физического воспитания подрастающего поколения в непрерывном образовании. Молодой ученый, (11), 381-383.)

12. Turdimurodov D. (2021). Formation and education of will in schoolchildren in the process of physical education lesson. Mental Enlightenment Scientific-Methodological Journal, 2021(02), - pp. 64-74. 